\title{
Industrial property management: sectorial aspect
}

\author{
Olena Stryzhak ${ }^{1, *}$, Olena Akhmedova ${ }^{1}$, Olena Sushchenko $^{1}$, and Mariia Pokolodna $^{2}$ \\ ${ }^{1}$ S. Kuznets Kharkiv National University of Economics, 61166, Kharkiv, Nauky Ave., 9a, Ukraine \\ ${ }^{2}$ O.M. Beketov National University of Urban Economy, 61002, Kharkiv, Marshal Bazhanov Str., 17, \\ Ukraine
}

\begin{abstract}
The necessity to determine the theoretical foundations of the effective management system organization for the creation and implementation of high technologies into the economic activity of domestic enterprises has been substantiated in the paper. The study objective is to formulate the theoretical foundations for the organization of an effective industrial property management system in the economic sector. The comparative characteristics of the industrial property items by their names, the form of legal protection and the classification features defined by the current legislation of Ukraine has been provided. The use of Structured Analysis and Design Technique (SADT) has been proposed in the paper to ensure the organization of the industrial property management process. As a practical implementation of the mechanism of organizational support for the process of industrial property management in the economic sector, the authors of the article have developed a business model for the organization of industrial property management in the economic sector with an in-depth structuring of business processes. The systematization of the industrial property management functions within the developed business model will help to identify the ways to improve the process of creation and sale of industrial property items in the mining industry.
\end{abstract}

\section{Introduction}

In the XXI century, knowledge and information have become the main driving force of social development, gradually displacing capital, labour and land from the production processes. These objective tendencies, inherent in the modern business system, require the search for new ways of increasing labour productivity, production efficiency, creation and production of competitive goods.

Latest technologies are the most important among the factors that ensure the stable competitive advantage of one country over the other. High technologies are radically changing manufacturing processes, contributing to the continuous growth of their owners' incomes. At the same time, only a country with the latest generation of technology and techniques can dominate in the international markets, which allows significantly limiting the use of natural resources, accordingly reduce the cost of production and dependence on

*Corresponding author: sssselllennnn@gmail.com 
the suppliers of resources. For Ukraine, the issues of reducing resources dependency in the context of complications of the relations with the Russian Federation are of particular importance.

Thus, in recent years one of the prerequisite for improving the functioning efficiency of both individual enterprises and economic systems as a whole is the use of the latest advances in science and technology. So far, Ukraine does not play any significant role as a producer of high-technology goods and services in the world market. In Ukraine the issues of crisis management concerning the reproduction and development of its scientific and technical potential requires the development of appropriate methodical and methodological support. First, it is necessary to determine the theoretical foundations of the organization of an effective management system for the creation and implementation of high technologies in the economic activity of domestic enterprises.

The creation of such a system should begin with the implementation of appropriate measures at the sectorial level as far because within the industry, businesses have similar technological processes, production organization, process management of a new product creation and implementation of industrial property objects, etc. In this context, the study objective is to formulate the theoretical foundations for the organization of an effective industrial property management system in the economic sector.

\section{Theoretical justification of the research}

For the first time the concept "industrial property" was used in the Article1 of the Paris Convention for the protection of industrial property in 1883, under which legal protection is given to object patents, utility models, industrial designs, trademarks, service marks, trade names, indications of source or appellations of origin, and the repression of unfair competition [1]. According to this convention, industrial property shall be understood in the broadest sense and shall apply not only to industry and commerce proper, but likewise to agricultural and extractive industries and to all manufactured or natural products, for example, wines, grain, tobacco leaf, fruit, cattle, minerals, mineral waters, beer, flowers, and flour.

Unlike the copyright items, most of which do not require registration or performing any other formalities, obtaining property right for the industrial property items requires registration, compliance with certain procedures and expertise, after which the property right is confirmed by official security documents such as patents, certificates, etc. That is why the issues of compliance with the procedure of obtaining legal protection, as well as the peculiarities and differences of industrial property protection in different countries, attract the scientists' close attention. B. A. Shahnazarov, for instance, notes that in most cases the principle of territoriality in the industrial property acts more pronounced than in copyright. The transformation of the fundamental principle of industrial property protection - the principle of the national regime into the principle of the international regime, which makes it possible to overcome the territorial principle of industrial property protection, is also very important [2].

It is worth mentioning that definitions and concepts of inventions still differ from country to country but meeting definite patentability requirements is of paramount importance to protect industrial property at any level. Several ways to extend a patent application abroad are proposed. A uniform European Patent Convention procedure for granting patents for inventions, recognised by all Contracting States, is available in Europe. Eurasian Patent Organization, African Intellectual Property Organization, African Regional Intellectual Property Organization operate to satisfy the needs for international cooperation and recognition of the intellectual and industrial items protection [3]. In this context, D. Marinova, M. McAleerb propose to identify the international rankings of the leading 
OECD countries concerning the industrial property items based on the analysis of the industrial property indicators that considerably influence the global development, such as advanced technology, openness, localisation, inventiveness, originality, which significantly influence the global development and are of definite importance [4].

The scholars also consider various aspects of industrial property management at the country level. Thus, some authors propose certain changes to national legislation in order to bring it into line with the international and European standards aiming at improving the procedure of the industrial property protection in the context of increased international cooperation. According to T.O. Garbuz, increasing the level of administrative and legal protection of industrial property in Ukraine will enhance their legal protection in accordance with the international and European standards [5]. L.M. Martínez, J.O. Guitart, P.L. Romero Suárez have researched the peculiarities of technology transfer at joint ventures of Cuba as the main form of international cooperation which are considered from the doctrinal and legislative point of view [6]. Using the example of Brazil's chemical industry, A. M. de Souza Antunes proves the need of knowledge transfer from universities and research institutions to industrial companies, and substantiates that such a transfer makes it possible to transform scientific knowledge into technology and thus enhance the country's [7].

Industrial property, being a part of intellectual property, is characterised by the fact that its items are used in the production processes and can be duplicated and transferred into industrial production.

The comparative description of industrial property items according to their names, form of legal protection and classification features as defined by the current legislation of Ukraine, is presented in Table. 1.

Table 1. Comparative analysis of industrial property items.

\begin{tabular}{|c|c|c|c|}
\hline $\begin{array}{c}\text { An industrial } \\
\text { property } \\
\text { item }\end{array}$ & Definition & \begin{tabular}{|c|} 
Form of \\
legal \\
protection
\end{tabular} & $\begin{array}{l}\text { Classification } \\
\text { features }\end{array}$ \\
\hline Invention & \multirow{2}{*}{$\begin{array}{l}\text { The result of human intellectual } \\
\text { activity in any field of technology } \\
\text { [8, art. 1], whose object may be: a } \\
\text { product (device, substance, strain } \\
\text { of microorganism, cell culture of } \\
\text { plants and animals, etc.); process } \\
\text { (method), as well as a new } \\
\text { application of a known product or } \\
\text { process [8, art. } 6]\end{array}$} & Patent & $\begin{array}{l}\text { Consistency with public } \\
\text { order, principles of } \\
\text { humanity and morality, } \\
\text { novelty, inventive level, } \\
\text { suitability for industrial use }\end{array}$ \\
\hline Utility model & & Patent & $\begin{array}{l}\text { Consistency with public } \\
\text { order, principles of } \\
\text { humanity and morality, } \\
\text { novelty, inventive level, } \\
\text { suitability for industrial use }\end{array}$ \\
\hline $\begin{array}{l}\text { Industrial } \\
\text { model }\end{array}$ & $\begin{array}{l}\text { The result of a person's creative } \\
\text { activity in the field of artistic } \\
\text { design [9, art. 1], whose object } \\
\text { may be a shape, drawing or } \\
\text { colouring, or a combination of } \\
\text { both, which determine the } \\
\text { appearance of an industrial } \\
\text { product and are intended to meet } \\
\text { aesthetic and ergonomic needs [9, } \\
\text { art. 5] }\end{array}$ & Patent & $\begin{array}{l}\text { Consistency with public } \\
\text { order, principles of } \\
\text { humanity and morality, } \\
\text { novelty, inventive level, } \\
\text { suitability for industrial use }\end{array}$ \\
\hline
\end{tabular}


Table 1 (continued). Comparative analysis of industrial property items.

\begin{tabular}{|c|c|c|c|}
\hline $\begin{array}{c}\text { An } \\
\text { industrial } \\
\text { property } \\
\text { item }\end{array}$ & Definition & $\begin{array}{l}\text { Form of } \\
\text { legal } \\
\text { protection }\end{array}$ & $\begin{array}{l}\text { Classification } \\
\text { features }\end{array}$ \\
\hline $\begin{array}{c}\text { Trade } \\
\text { (commercial) } \\
\text { name }\end{array}$ & $\begin{array}{l}\text { The name by which a legal entity or a } \\
\text { citizen engaged in the entrepreneurial } \\
\text { activity without the creation of a legal } \\
\text { entity, identify themselves in the market } \\
\text { and which is used to identify them in } \\
\text { economic (commercial) relations [10] }\end{array}$ & Registration & $\begin{array}{l}\text { Genuineness, } \\
\text { exclusivity, } \\
\text { constancy } \\
\text { (inalterability) }\end{array}$ \\
\hline $\begin{array}{l}\text { Trademark } \\
\text { (sign for } \\
\text { goods and } \\
\text { services) }\end{array}$ & $\begin{array}{l}\text { Any designation or any combination of } \\
\text { designations that are capable of } \\
\text { distinguishing the goods (services) that are } \\
\text { produced (provided) by one person from } \\
\text { the goods (services) that are produced } \\
\text { (provided) by other persons. Such } \\
\text { designations may include, in particular, } \\
\text { words, letters, numbers, pictorial elements, } \\
\text { colour combinations [11, art. 492]. Any } \\
\text { designation or any combination of } \\
\text { designations, such as words, including } \\
\text { proper names, letters, numbers, pictorial } \\
\text { elements, colours and colour } \\
\text { combinations, and any other combination } \\
\text { of such designations [12, art. 5] }\end{array}$ & $\begin{array}{c}\text { Certificate, } \\
\text { status of a } \\
\text { well-known } \\
\text { sign }\end{array}$ & $\begin{array}{l}\text { Distinctiveness, } \\
\text { suitability for } \\
\text { marking goods, } \\
\text { compliance with } \\
\text { the requirements } \\
\text { of industrial } \\
\text { aesthetics and } \\
\text { ergonomics, } \\
\text { compliance with } \\
\text { public order, } \\
\text { principles of } \\
\text { humanity and } \\
\text { morality }\end{array}$ \\
\hline $\begin{array}{c}\text { Geographical } \\
\text { indication }\end{array}$ & $\begin{array}{l}\text { The name of a place that identifies a } \\
\text { product originating from a particular } \\
\text { geographical location and having a } \\
\text { particular quality, reputation or other } \\
\text { characteristics, predominantly determined } \\
\text { by that geographical origin, and at least } \\
\text { one of the stages of production } \\
\text { (manufacturing (production) and / or } \\
\text { processing, and / or preparation) is carried } \\
\text { out in a defined geographical area }[13, \text { art. } \\
1] \text {. }\end{array}$ & $\begin{array}{l}\text { Data entry } \\
\text { in the } \\
\text { register }\end{array}$ & $\begin{array}{l}\text { Characteristics of } \\
\text { the product } \\
\text { (service) and the } \\
\text { boundaries of the } \\
\text { geographical } \\
\text { location of its } \\
\text { origin, fixed by } \\
\text { the state } \\
\text { registration of } \\
\text { intellectual } \\
\text { property right to } \\
\text { the geographical } \\
\text { indication }\end{array}$ \\
\hline $\begin{array}{l}\text { Name of the } \\
\text { place of } \\
\text { goods origin }\end{array}$ & $\begin{array}{l}\text { A type of geographical indication, which } \\
\text { means a name that identifies a product that } \\
\text { originates from a specific geographical } \\
\text { location and which has specific qualities or } \\
\text { properties, solely or mainly determined by } \\
\text { a specific geographical environment with } \\
\text { inherent natural and human factors, and all } \\
\text { stages of production (manufacturing } \\
\text { (extraction) and / or processing and / or } \\
\text { preparation) are carried out in a defined } \\
\text { geographical area [13, art. 1] }\end{array}$ & $\begin{array}{c}\text { Registration } \\
\text { certificate }\end{array}$ & $\begin{array}{l}\text { Connection to a } \\
\text { specific place, } \\
\text { indication of a } \\
\text { certain quality, } \\
\text { genuineness, } \\
\text { resolution ability, } \\
\text { generally known, } \\
\text { suitability for } \\
\text { marking goods, } \\
\text { collective } \\
\text { character of use } \\
\end{array}$ \\
\hline
\end{tabular}


Table 1 (continued). Comparative analysis of industrial property items.

\begin{tabular}{|c|c|c|c|}
\hline $\begin{array}{l}\text { An industrial } \\
\text { property item }\end{array}$ & Definition & $\begin{array}{c}\text { Form of } \\
\text { legal } \\
\text { protection }\end{array}$ & $\begin{array}{l}\text { Classification } \\
\text { features }\end{array}$ \\
\hline $\begin{array}{l}\text { Scientific } \\
\text { discovery }\end{array}$ & $\begin{array}{l}\text { Establishment of previously } \\
\text { unknown, but objectively existing } \\
\text { laws, properties and phenomena of } \\
\text { the material world, which bring } \\
\text { fundamental changes to the level of } \\
\text { scientific knowledge [11, art. } 457]\end{array}$ & Diploma & $\begin{array}{l}\text { Novelty, priority, } \\
\text { scale } \\
\text { (fundamentality), } \\
\text { reliability }\end{array}$ \\
\hline $\begin{array}{l}\text { Arrangement } \\
\text { of a } \\
\text { semiconductor } \\
\text { product }\end{array}$ & $\begin{array}{l}\text { A set of related images, either fixed } \\
\text { or encoded in a certain order, } \\
\text { constituting the three-dimensional } \\
\text { configuration of the layers, which } \\
\text { make the semiconductor product } \\
\text { and in which each image contains a } \\
\text { configuration or part of a } \\
\text { semiconductor product } \\
\text { configuration at any stage of its } \\
\text { production }[14, \text { art. } 1]\end{array}$ & Certificate & Originality \\
\hline $\begin{array}{l}\text { Proposal for } \\
\text { a technical } \\
\text { improvement }\end{array}$ & $\begin{array}{l}\text { A proposal recognized by a legal } \\
\text { entity that contains a technological } \\
\text { (technical) or organizational } \\
\text { solution in any sphere of its activity, } \\
\text { whose object may be a material } \\
\text { object or process [11, art. } 481]\end{array}$ & Certificate & $\begin{array}{l}\text { Correspondence to the } \\
\text { company profile, local } \\
\text { novelty, utility for the } \\
\text { enterprise }\end{array}$ \\
\hline $\begin{array}{l}\text { Termination } \\
\text { of unfair } \\
\text { competition }\end{array}$ & $\begin{array}{l}\text { Any competition actions that } \\
\text { contradict the rules, trade and other } \\
\text { honest practices in entrepreneurial } \\
\text { activity }[15, \text { art. } 1]\end{array}$ & - & $\begin{array}{l}\text { Misuse of the } \\
\text { goodwill of a business } \\
\text { entity; obstructing a } \\
\text { business entity in the } \\
\text { process of competition } \\
\text { and achieving an } \\
\text { undue competitive } \\
\text { advantage; collecting, } \\
\text { disclosure and misuse } \\
\text { of a trade secret }\end{array}$ \\
\hline $\begin{array}{l}\text { Trade secret } \\
\text { (know-how) }\end{array}$ & $\begin{array}{l}\text { Information that is confidential in } \\
\text { the sense that it is in a whole or in } \\
\text { some form and totality of its } \\
\text { constituents is unknown and not } \\
\text { easily accessible to persons who } \\
\text { normally deal with the type of } \\
\text { information to which it belongs and } \\
\text { in this connection it is of } \\
\text { commercial value and was } \\
\text { subjected to adequate measures to } \\
\text { preserve its secrecy under the } \\
\text { current circumstances, taken by the } \\
\text { person who lawfully controls this } \\
\text { information [11, art. 505] }\end{array}$ & $\begin{array}{l}\text { Does not } \\
\text { require } \\
\text { registration } \\
\text { or } \\
\text { registration } \\
\text { for indication } \\
\text { purposes }\end{array}$ & $\begin{array}{l}\text { Physical monopoly on } \\
\text { a certain body of } \\
\text { knowledge, } \\
\text { universality, applies } \\
\text { only to entrepreneuria } \\
\text { activity }\end{array}$ \\
\hline
\end{tabular}


Table 1 (continued). Comparative analysis of industrial property items.

\begin{tabular}{|c|c|c|c|c|}
\hline $\begin{array}{l}\text { An industrial } \\
\text { property item }\end{array}$ & & Definition & $\begin{array}{l}\text { Form of } \\
\text { legal } \\
\text { protection }\end{array}$ & $\begin{array}{l}\text { Classification } \\
\text { features }\end{array}$ \\
\hline \multirow{3}{*}{$\begin{array}{l}\text { Selective } \\
\text { breeding } \\
\text { achievements }\end{array}$} & \multicolumn{2}{|c|}{$\begin{array}{l}\text { Result of a scientific and practical } \\
\text { activity which creates varieties and } \\
\text { hybrids of plants and breeds of animals } \\
\text { with specified characteristics }\end{array}$} & \multirow{3}{*}{$\begin{array}{l}\text { Patent, } \\
\text { certificate } \\
\text { of } \\
\text { authorship }\end{array}$} & \multirow{3}{*}{$\begin{array}{l}\text { Solution of a specific } \\
\text { practical problem, } \\
\text { novelty, } \\
\text { distinctiveness, } \\
\text { homogeneity, } \\
\text { stability }\end{array}$} \\
\hline & $\begin{array}{l}\text { Plant } \\
\text { variety }\end{array}$ & $\begin{array}{l}\text { A separate group of plants } \\
\text { (clone, lineage, hybrid of the } \\
\text { first generation, population) } \\
\text { within the lowest known } \\
\text { botanical taxon (genus, } \\
\text { species, variety), regardless of } \\
\text { whether it satisfies the } \\
\text { conditions of legal protection } \\
{[16, \text { art. 1] }}\end{array}$ & & \\
\hline & $\begin{array}{c}\text { Breeding } \\
\text { animal }\end{array}$ & $\begin{array}{l}\text { Purebred or obtained } \\
\text { according to the approved } \\
\text { breed improvement program } \\
\text { animal, registered in the state } \\
\text { books of breeding animals, } \\
\text { has a breeding (genetic) value } \\
\text { and can be used in the } \\
\text { breeding process in } \\
\text { accordance with the programs } \\
\text { of breeding [17, art. } 1]\end{array}$ & & \\
\hline
\end{tabular}

Despite the system of legislative regulation in the sphere of industrial property, the complex state approach to the processes of informational and technical support, expertise, value estimation of the industrial property items, the mechanism of state support for the development, creation and use of industrial items is not actually implemented in Ukraine. Management of the industrial property at the state level is limited to issuing a copyright protection, notwithstanding the creation of favourable conditions for the sale of licenses abroad, which provides an opportunity to receive foreign currency receipts, to both individual enterprises and the state as a whole.

Thus, there is an important problem in the field of industrial property management, especially with regard to the implementation of the mechanism of direct relationships between authors and developers of industrial property items and the enterprises and institutions that utilise them. According to the authors of this paper, the basis of such relationships should be laid at the industry level that is determined by such factors as the subordination unity of institutions for the development and implementation of industrial property units, the similarity of technological processes of production and distribution of products within a certain industry, etc. Addressing these pressing issues will significantly reduce the information and transaction costs associated with the use of industrial property items, improve the overall condition of the industrial property management infrastructure in the mining industry.

In view of the above stated, industrial property management in the sectorial context requires the development of new methodological approaches to its organization in the mining industry. 


\section{Conceptual modelling}

Due to the fact that the industrial property management system is a set of interrelated actions, the use of SADT (Structured Analysis and Design Technique) methodology is proposed to ensure the organization of the industrial property management process.

As a practical implementation of the mechanism of organizational support for the process of industrial property management in the industry, the authors of the paper have developed a business model for the organization of industrial property management at the industry level with the advanced structuring of business processes (Fig. 1). The business model is a set of hierarchical actions that transform an object and are graphically represented within the system as separate business processes with the help of entry, exit, control, and execution arrows.

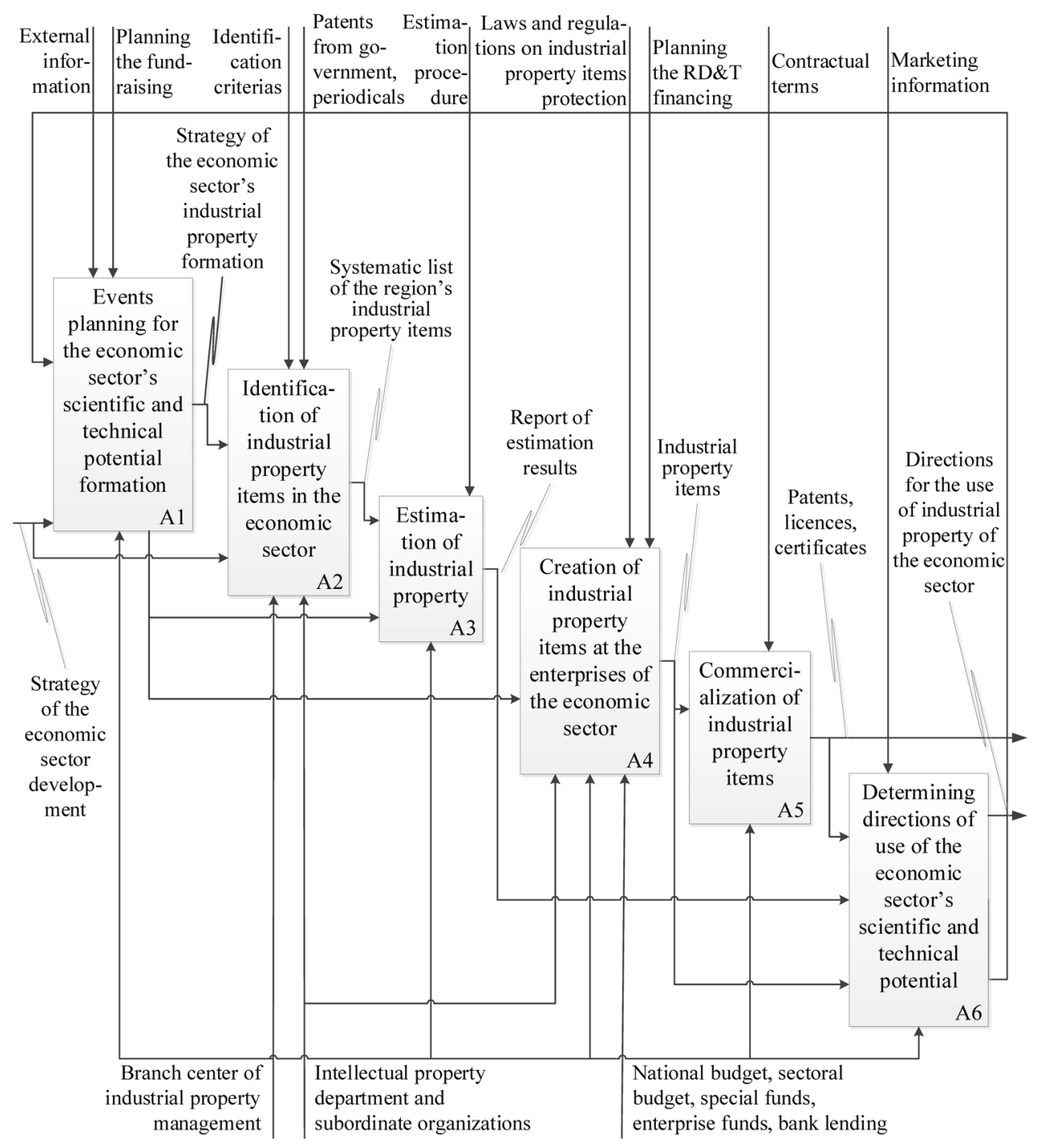

Fig. 1. Business model of industrial property management in the economic sector.

Description of the blocks A1 - A6 of the industrial property management presented in Fig. 1, is given below. 
A1. Events planning for the economic sector's scientific and technical potential formation.

The industry development strategy should include measures for the creation, evaluation and commercialization of industrial property items, the use of which gives competitive advantages to enterprises in the national and international markets. Events planning for the economic sector's scientific and technical potential formation is developed on the basis of the received external information and the corresponding plans for attracting resources. The result of this phase is a strategy for the economic sector's scientific and technical potential formation. The general provisions of this strategy should be defined by the relevant ministries and agencies and agreed upon with the leading industry enterprises.

A2. Identification of industrial property items in the economic sector.

At this stage, the value of the existing industrial property assets for the economic sector is determined. The identification of industrial property items is carried out on the basis of certain criteria, taking into account data on the patentability of industrial property items and information obtained from periodicals. The result of this step is a systematic list of industrial property items within the economic sector. Such a list provides an opportunity for direct and full access of legal entities and individuals to patent information.

A3. Estimation of industrial property. items:

In practice, the following basic approaches are used to evaluate industrial property

1) cost or investment approach, which includes the methods for determining actual costs, renewable cost, replacement cost;

2) market or comparative approach, which involves the use of methods of comparative sales, the market of intellectual property, exemption from royalties, expert assessments;

3) income or financial approach, the main methods of which are the methods of discounting, capitalization of income, economic effect, royalty.

The choice of the estimation method depends on the purpose of the estimation and the type of industrial property item. Based on the results of the estimation, a report on its results is issued. Estimation of industrial property items solves the problem of their reflection in the accounting and financial statements as fixed capital, which allows the mining companies, firstly, to charge depreciation for financing the reproduction of industrial property items, and secondly, to reduce a part of profit that is subjected to tax due to depreciation of these objects.

A4. Creation of industrial property items at the enterprises of the economic sector.

The creation of industrial property items, which is aimed at enhancing the competitiveness of mining enterprises, requires adequate financial support. This is a rather difficult issue for Ukraine due to the lack of funds allocated for the development of science and technology. The state budget consolidates the funds obtained from the disposal of the rights on the research and development results belonging to the state. These funds finance specific targeted programs and support measures to improve the protection of industrial property rights. In addition to the budgetary funds, the creation of industrial property items at the mining enterprises can be financed by regional budgets, special state and private innovation and venture funds, by attracting foreign investors, the enterprise development fund, and bank lending.

A5. Commercialization of industrial property items.

The essence of commercialization of industrial property items is to link research and technology projects to market needs.

The current system of commercialization of industrial property items in Ukraine needs to be substantially improved, and, according to the views of the paper authors, should be focused on reducing the terms of registration of industrial property rights and improving the quality of patent examination; stimulating developments by introducing tax reliefs for 
businesses and organizations practicing and implementing them; supporting the fundamental researches aimed at creating absolutely new products, etc. Solving the problem of commercialization of industrial property items will increase the level of the national products competitiveness in the international markets.

A6. Determining directions of use of the economic sector's scientific and technical potential.

The essence of this stage is to implement into practice the results of intellectual activity. Besides, the realization of industrial property rights can be one of the sources of RD\&T financing.

The practical significance of the proposed approach to the organization of industrial property management in the economic sector is to direct the activities of mining enterprises to the creation, support and development of intellectual resources and the corresponding increase of the scientific and technical potential of the industry.

\section{Conclusion}

The functional model of the organization of industrial property management AS-IS offered in the paper allows to understand the necessity of changes for improvement of the management process organization. This model is commonly used to identify certain deficiencies in the organization of business processes at the enterprise. The imperfections found in the AS-IS model can be corrected by creating the TO-BE model, the ideal business process organization model. This model is necessary for evaluation of the benefits of implementing an industrial property management information system in the economic sector. The systematization of industrial property management functions within the developed business model will help to identify ways to improve the process of creation and distribution of industrial property items in the mining industry. The developed model can also be used as a methodical basis for the analysis of new business processes in the economic sector, which is the prospect of further scientific developments in this direction.

\section{References}

1. Paris Convention for the Protection of Industrial Property of March 20, 1883. Retrieved from https://www.wipo.int/treaties/en/text.jsp?file_id=288514\#P71_4054

2. Shahnazarov, B. A. (2019). Transformation of the basic principles of industrial property protection in cross-border relations in the present-day conditions, Lex Russica, 11(156), 47-55.

3. Barbieri, M. (2017). Innovation and Industrial Property Rights: Technical Report, SSRN Electronic Journal, Retrieved from https://afly.co/xdd2

4. Marinova, D., McAleerb, M. (2003). International Rankings of Industrial Property. Retrieved from https://www.researchgate.net/publication/228430025

5. Harbuz, T. (2018). Industrial Property and Space Activities: Legal Protection, Advanced Space Law, (1), 50-56

6. Martínez, L.M., Guitart, J.O., Romero Suárez, P.L. The management of Industrial Property in technology transfer: analysis in Cuba, Revista de derecho, universidad del norte, 36 (2011)

7. Adelaide Maria de Souza Antunes. Innovation \& Sndustrial property \& The chemicals industry, Quim. Nova, 36, 10 (2013)

8. Zakon Ukrayiny "Pro okhoronu prav na vynakhody i korysni modeli" vid 15.12.93 r. No.3687-XII. Vidomosti Verkhovnoyi Rady Ukrayiny, 7 (1994) 
9. Zakon Ukrayiny "Pro okhoronu prav na promyslovi zrazky" vid 15.12.1993 r. No.3688KHII. Vidomosti Verkhovnoyi Rady Ukrayiny, 7 (1994)

10. Vyshchiy hospodarskyy sud Ukrayiny. Ohlyadovyy lyst No. 01-06/521 vid 28.02.2017 r. "Pro deyaki pytannya praktyky zastosuvannya hospodarskymy sudamy zakonodavstva pro zakhyst prav na obyekty intelektualnoyi vlasnosti". Retrieved from https://zakon.rada.gov.ua/laws/show/v_521600-17

11. Tsyvilnyy kodeks Ukrayiny na 01.0̄1.2004 r. Ofitsiyne vydannya (2004). Kyiv: Parlamentske vydavnytstvo

12. Zakon Ukrayiny "Pro okhoronu prav na znaky dlya tovariv i posluh" vid 15.12.1993 r. No. 3689-KHII. Vidomosti Verkhovnoyi Rady Ukrayiny, 7 (1994)

13. Zakon Ukrayiny "Pro okhoronu prav na zaznachennya pokhodzhennya tovariv" vid 16.06.1999 r. No. 752-KHIV. Vidomosti Verkhovnoyi Rady Ukrayiny, 32 (1999)

14. Zakon Ukrayiny "Pro okhoronu prav na komponuvannya napivprovidnykovykh vid 19.09.2019 r. No. 111-IX (111-20), Vidomosti Verkhovnoyi Rady Ukrayiny, 8

15. Zakon Ukrayiny "Pro zakhyst vid nedobrosovisnoyi konkurentsiyi" vid 07.07.1996 r. No.236/96-VR. Vidomosti Verkhovnoyi Rady Ukrayiny, 36 (1996)

16. Zakon Ukrayiny "Pro okhoronu prav na sorty roslyn" vid 15.12.1993 r. No.3116-KHII. Vidomosti Verkhovnoyi Rady Ukrayiny, 21 (1993)

17. Zakon Ukrayiny "Pro pleminnu spravu u tvarynnytstvi" vid 15.12.1993 r. No.3691KHII. Vidomosti Verkhovnoyi Rady Ukrayiny, 6 (2000) 